Journal of Medicinal Plants

Institute of

Medicinal Plants

Journal homepage: $\underline{w w w . j m p . i r}$

Research Article

\title{
Polyherbal tablet based on Iranian traditional medicine
}

\section{Maedeh Rezghi ${ }^{1,2}$, Seyed Alireza Mortazavi ${ }^{3}$, Shirin Fahimi ${ }^{2}$, Rasool Choopani ${ }^{4}$, Mohammad Abbas Sheikholeslami ${ }^{5}$, Maryam Hamzeloo-Moghadam ${ }^{2, *}$}

${ }^{1}$ Student Research Committee, Shahid Beheshti University of Medical Sciences, Tehran, Iran

${ }^{2}$ Traditional Medicine and Materia Medica Research Center and Department of Traditional Pharmacy, School of Traditional Medicine, Shahid Beheshti University of Medical Sciences, Tehran, Iran

${ }^{3}$ Department of Pharmaceutics, School of Pharmacy, Shahid Beheshti University of Medical Sciences, Tehran, Iran

${ }^{4}$ Department of Traditional Medicine, School of Traditional Medicine, Shahid Beheshti University of Medical Sciences, Tehran, Iran

${ }^{5}$ Department of Pharmacology, School of Medicine, Shahid Beheshti University of Medical Sciences, Tehran, Iran

\begin{tabular}{|c|c|}
\hline ARTICLE INFO & ABSTRACT \\
\hline $\begin{array}{l}\text { Keywords: } \\
\text { Monzej-e-balgham } \\
\text { Quality control } \\
\text { Tablet } \\
\text { Total phenol content } \\
\text { Iranian traditional medicine }\end{array}$ & $\begin{array}{l}\text { Background: Medicinal plants have important role for prevention and treatment } \\
\text { of diseases regarding their traditional uses. In Iranian traditional medicine } \\
\text { (ITM), herbal medicines have been considered as the key agents in the treatment } \\
\text { of wide ranges of disorders. Traditional preparations can be reformulated to } \\
\text { achieve pharmacopoeia standards as modern medicines. Objective: In this } \\
\text { research, a polyherbal tablet namely "Monzej-e-balgham", which is widely used } \\
\text { for treating different diseases, has been formulated and quality control } \\
\text { assessments have been done to present a proper formulation. Methods: } \\
\text { Glycyrrhiza glabra L., Rosa x damascena Herm., Adiantum capillus-veneris L., } \\
\text { Onopordum acanthium L., Vitis vinifera L., Ficus carica L. and Foeniculum } \\
\text { vulgare Mill. were extracted with water, filtered, concentrated and dried with } \\
\text { spray drying method. Thirteen tablets formulations by direct compression and } \\
\text { pre- and post- formulation analyses were prepared. Finally, the most proper } \\
\text { formulation was selected and evaluated physicochemically and } \\
\text { microbiologically according to standard protocols. The total phenol content as } \\
\text { marker of the tablets was determined and accelerated stability tests were } \\
\text { conducted ( } 40 \text { C } / 75 \% \text { RH) as per ICH guidelines for six months. Results: For } \\
\text { the selected formulation (F2), the hardness, weight variation, friability, } \\
\text { disintegration time and drug release were determined as } 6.78 \pm 0.28 \mathrm{~kg} / \mathrm{cm}{ }^{2} \text {, } \\
714.36 \pm 1.71 \text { mg, } 0.79 \pm 0.05 \% \text {, } 10.18 \pm 0.39 \text { min and } 97.67 \pm 0.16 \% \text { in one } \\
\text { hour, respectively. The amount of total phenol was found to be } 25.15 \pm 0.13 \\
\text { mg/tablet. Microbial levels were in agreement with requirements. In the } \\
\text { accelerated stability tests, no significant changes were observed. Total phenol } \\
\text { content decreased } 1.03 \% \text { during } 6 \text { months. Conclusion: After completing } \\
\text { complementary tests such as in vivo and clinical trials, the formulated tablet (F2) } \\
\text { could be presented for mass production. }\end{array}$ \\
\hline
\end{tabular}

Abbreviations: ITM: Iranian traditional medicine; ICH: The International Council for Harmonisation of Technical Requirements

* Corresponding author: mhmoghadam@sbmu.ac.ir

doi: $10.29252 /$ jmp.20.77.15

Received 19 February 2020; Received in revised form 26 August 2020; Accepted 9 September 2020

(C) 2020. Open access. This article is distributed under the terms of the Creative Commons Attribution-NonCommercial 4.0 International License (https://creativecommons.org/licenses/by-nc/4.0/) 


\section{Introduction}

Herbal medicines have been used to treat various disorders since ancient times [1, 2]. Despite the significant progress in modern medicine in recent decades, plants still play a considerable role in health care and interest in drugs derived from plants has increased dramatically [3]. At present, the major pharmaceutical companies are interested in researching medicinal plants as sources for new lead structures, as well as for the development of standardized phytotherapeutic agents with proved efficacy, safety and quality [1]. Usually, herbal medicinal products are very popular in developing countries with a long tradition in the use of medicinal plants. However, modern scientific methods should be used to confirm the claims related to the therapeutic effects of the plants in the traditional medical system $[1,4]$.

Among various kinds of traditional and complementary systems of medicine, Iranian traditional medicine (ITM), is one important traditional approach to medicine that has promoted healthy life $[4,5]$. In ITM, medicinal plants have been used to treat different diseases [6]. The present study tried to formulate one traditional drug form, namely "Monzej-ebalgham". The medications that maturate phlegm (balgham) are widely used in ITM for the treatment of different diseases such as stroke [7, 8], hemiplegia due to ischaemic stroke [9], cardiovascular disease risk factors such as metabolic abnormalities like abdominal obesity, high cholesterol, high blood pressure and high blood glucose [10], overweight [11], atherosclerosis [12], premature ovarian failure (POF) [13], impotence [14], bronchitis [15] and vitiligo $[16,17]$ according to modern studies. Various formulations of "Monzej-e-balgham" could be found in important traditional pharmacopeia and the types of plants have been proposed in different medical prescriptions.
Among them, a manuscript [18] in the form of "Matbookh" (decoction), containing the roots of Glycyrrhiza glabra L., fruits of Foeniculum vulgare Mill., aerial parts of Adiantum capillusveneris L., fruits of Vitis vinifera L., fruits of Ficus carica L., flowers of Rosa $x$ damascena Herrm. and seeds of Onopordum acanthium L. was selected. The prescription was decided to be converted into new dosage form for better acceptance and easier usage by patients compared to the traditional formulation [4]. Solid dosage forms like tablet is more desirable in comparison with the liquid dosage forms because of more stability, uniformity and correct potency, less microbial problems, better flavor masking and easier transportation [2]. In this study, tablets of "Monzej-e-balgham" have been prepared according to prescriptions in ITM and standard pharmaceutical controls of the tablets have been performed to present a qualified formulation for usage.

\section{Materials and Methods}

\subsection{Chemicals}

All chemicals were of analytical grade. Sodium carbonate was provided from Sigma, Germany and other chemicals and solvents were prepared from Merck, Germany.

\subsection{Equipment}

The friability of tablets was determined using Pharma-test friabilator (Model TAR, Erweka, Germany). Hardness of the tablets was evaluated by hardness tester (Model TBH28, Erweka, Germany). Disintegration time was measured using disintegration testers (Model ZT3, Erweka, Germany) and dissolution behavior was determined with dissolution testers (Kavosh Co., Iran). The tablets were pressed with Excentric Tabletting Machine (EKO) (Model single-punch tablet machine, Erweka, Germany). 


\subsection{Plant material}

Required plants for preparation of the tablets were purchased from Tehran local market in 2017. The samples were identified by botanists at the Herbarium of Traditional Medicine and Materia Medica Research Center, Shahid Beheshti University of Medical Sciences, Tehran, Iran. Herbal Market Samples (HMS) of the fruits of $F$. carica (No. 490), roots of G. glabra (No. 494), fruits of $F$. vulgare (No. 492), flowers of $R$. damascena (No. 488), aerial parts of A. capillus-veneris (No. 491), fruits of $V$. venifera (No. 489), and seeds of $O$. acanthium (No. 493) have been deposited at the Herbarium of TMRC.

\subsection{Physicochemical parameters analysis of plant materials}

Quality control assessments of plants such as loss on drying, foreign matters, total ash, acid insoluble ash, water soluble extractive and alcohol soluble extractives were carried out according to the Pharmacopeia [19-21].

\subsection{Formulation of polyherbal tablets}

According to the selected prescription [18] Ficus carica (6 parts), Adiantum capillus-veneris (3 parts), Rosa x damascena and Glycyrrhiza glabra (2 parts), Foeniculum vulgare and Onopordum acanthium (1.3 parts) and Vitis vinifera (1 part) were crushed and coarse powdered and then mixed and extracted with distilled water (plant: water 1:10 w/v) using infusion method at $90{ }^{\circ} \mathrm{C}$ for two hours. After extraction, the mixture was filtered, concentrated and dried with spray drying method to produce a dry powder from the extract.

Amount of dry extracts used in tablets was $500 \mathrm{mg}$ based on daily dosages of traditional usages. Thirteen formulations were prepared with various ingredients containing microcrystalline cellulose, lactose monohydrate, croscarmellose sodium, colloidal silicon dioxide and maltodextrin (F1-F13) (Table 1). The ingredients were mixed in various ratios according to formulation design and they were prepared using direct compression method. Pre- and post- formulation tests were used for controlling of polyherbal tablets. According to the results of the tests, the most suitable formulation (F2) was selected.

\subsection{Quality control tests}

The ideal properties of a tablet are compactness, rapid production capability, physical and chemical stability and efficacy. Therefore, various physiochemical tests and pharmaceutical parameters have been developed to monitor suitability of tablets such as powders angle of repose, Carr's index and Hausner ratio, also tablets appearance, diameter, thickness, weight variation, hardness, friability, disintegration times, dissolution behavior studies and drug assay according to standard methods [22].

\subsection{Preformulation studies of powder mixture}

The flowability of formulations was calculated on the basis of Carr's index, Hausner ratio and angle of repose $[23,24]$.

\subsubsection{Angle of repose}

Angle of repose was determined by fixed funnel method and calculated regarding the following formula. In this formula " $\mathrm{H}$ " is height and " $R$ " is radius of granules:

\section{Tan alpha=H/R}

Alpha: angle of repose 
Table 1. Ratio of different constituents in the experimental formulations

\begin{tabular}{|c|c|c|c|c|c|c|c|}
\hline \multirow[b]{2}{*}{ Formulations } & \multicolumn{7}{|c|}{ Ingredients } \\
\hline & $\begin{array}{c}\text { Herbal } \\
\text { powder } \\
(\mathbf{m g})\end{array}$ & $\begin{array}{l}\text { Maltodextrin } \\
\quad \text { (mg) }\end{array}$ & $\begin{array}{l}\text { Colloidal } \\
\text { silicon } \\
\text { dioxide } \\
(\mathbf{m g})\end{array}$ & $\begin{array}{l}\text { Microcrystalline } \\
\text { cellulose (Avicel } \\
\text { 102) (mg) }\end{array}$ & $\begin{array}{l}\text { Croscarmellose } \\
\text { sodium }(\mathbf{m g})\end{array}$ & $\begin{array}{c}\text { Lactose } \\
\text { monohydrate } \\
(\mathbf{m g})\end{array}$ & $\begin{array}{l}\text { Total } \\
(\mathbf{m g})\end{array}$ \\
\hline F1 & 500 & 180 & 20 & - & - & - & 700 \\
\hline F2 & 500 & 180 & 20 & - & 14 & - & 714 \\
\hline F3 & 500 & 180 & 20 & - & 35 & - & 735 \\
\hline F4 & 500 & 180 & 20 & - & 70 & - & 770 \\
\hline F5 & 500 & 180 & 20 & 126 & 14 & - & 840 \\
\hline F6 & 500 & 180 & 20 & 105 & 35 & - & 840 \\
\hline F7 & 500 & 180 & 20 & 70 & 70 & - & 840 \\
\hline F8 & 500 & 180 & 20 & 140 & - & - & 840 \\
\hline F9 & 500 & 180 & 20 & 70 & - & 70 & 840 \\
\hline F10 & 500 & 180 & 20 & - & - & 140 & 840 \\
\hline F11 & 500 & 180 & 20 & - & 14 & 126 & 840 \\
\hline F12 & 500 & 180 & 20 & - & 35 & 105 & 840 \\
\hline F13 & 500 & 180 & 20 & - & 70 & 70 & 840 \\
\hline Function & $\begin{array}{c}\text { Active } \\
\text { ingredient }\end{array}$ & Binder & $\begin{array}{l}\text { Glidant, } \\
\text { disintegrant }\end{array}$ & $\begin{array}{c}\text { Binder, } \\
\text { Direct compression } \\
\text { excipient }\end{array}$ & Disintegrant & $\begin{array}{l}\text { Bind, Direct } \\
\text { compression } \\
\text { excipient }\end{array}$ & - \\
\hline
\end{tabular}

\subsubsection{Compressibility index (Carr's index)}

It was measured by using Bulk Density (BD) and Tapped Density (TD).

Sufficient quantity of powder blend was introduced to a measuring cylinder of $100 \mathrm{ml}$. The cylinder was tapped 100 times and the tapped volume of packing was noted. BD and TB were calculated by [25]:

$\mathrm{BD}=$ Weight of powdered blend/Untapped volume of the powder

$\mathrm{TD}=$ Weight of powdered blend/Tapped volume of the powder

Carr's Index $=($ Tapped Density - Bulk Density $\times 100)$ / tapped Density

\subsubsection{Hausner ratio}

It is an index of ease of powder flow and was measured using the following formula:

Hausner ratio $=$ Tapped Density/ Bulk Density

\subsection{Formulation studies of tablets}

\subsubsection{Hardness}

Using a hardness tester, crushing strength of tablets was evaluated. Six tablets of each formulation were selected randomly and the average force to the tablet to cause fracture was recorded.

\subsubsection{Friability}

Friability test determines the ability of tablets to withstand abrasion during packaging, handling, and shipping processes. Ten preweighed tablets were placed in the friability tester and rotated at $25 \mathrm{rpm}$ for $4 \mathrm{~min}$ (100 revolutions). Then, the tablets were taken out from the tester and reweighed. The weight loss due to abrasion was expressed as percentage. A maximum weight loss of not more than $1 \%$ is acceptable [26].

The friability was determined by the following formula:

$\%$ Friability $=($ Initial weight - Weight after friability testing $\times 100) /$ Initial weight

\subsubsection{Weight variation}

For weight variation analysis, ten tablets were chosen randomly and weighed individually; the average weight and standard deviation (SD) were then calculated. 


\subsubsection{Disintegration time}

Six tablets were selected for the test and were placed in distilled water at temperature of $37 \pm 1.0^{\circ} \mathrm{C}$ using a disintegration tester; time of complete disintegration was noted.

\subsubsection{Dissolution rate}

Dissolution test of polyherbal tablets was performed on six tablets using the paddle method according to the United States Pharmacopoeia (USP) guidelines [27]. Dissolution apparatus type II at a speed of $75 \mathrm{rpm}$, with $900 \mathrm{ml}$ distilled water as the dissolution medium was used and the temperature was maintained at $37 \pm 0.5^{\circ} \mathrm{C}$. Fifteen $\mathrm{ml}$ of the sample was withdrawn, replenished with fresh and equivalent medium at predetermined time intervals $(15,30,45,60 \mathrm{~min})$ and the amount of dissolved total phenol of each withdrawn sample was calculated using UV spectroscopy by comparing the measured absorbance with the calibration curve prepared for that purpose. Quantity (Q) more than $75 \%$ was considered acceptable for dissolution test [27].

\subsubsection{Total phenol content assay}

Ten tablets were weighed and powdered. An accurately weighed portion of the powder, equivalent to one tablet, was dissolved and diluted to $100 \mathrm{ml}$ distilled water. The solution was allowed to shake for $1 \mathrm{~h}$ and was then filtered. Total phenolic contents of samples were determined by Folin-Ciocalteu reagent. Two ml of diluted sample, $1 \mathrm{ml}$ Folin-Ciocalteu reagent and $10 \mathrm{ml}$ distilled water were mixed and afterwards aqueous solution of sodium carbonate $(29 \%, w / v)$ was added to the mixture up to $25 \mathrm{ml}$ and allowed to stand at room temperature for 30 min. Absorbance was measured by UV spectrophotometry at $760 \mathrm{~nm}$. Total phenol content was calculated on the basis of the standard calibration curve of pyrogallol. All measurements were carried out at room temperature in triplicate.

\subsection{Stability evaluation of polyherbal tablets}

The evaluation of drug accelerated stability was performed as per ICH guidelines. The tablets were stored at $40{ }^{\circ} \mathrm{C} / 75 \% \mathrm{RH} \pm 2{ }^{\circ} \mathrm{C} / 5 \% \mathrm{RH}$ up to 6 months. Physicochemical specifications of the tablets were evaluated afterwards [28].

\subsection{Statistical analysis}

The data were analyzed using ANOVA (oneway analysis of variance) followed by Tukey's post hoc test. $\mathrm{P}<0.05$ was considered as statistically significant.

\section{Results}

In this research, several of tablets were formulated based on Iranian traditional medicine. Polyherbal tablets with different ratios of excipients have been shown in Table 1 and precompression studies results of powder mixture of all formulations have been presented in Table 2.

Polyherbal tablets were prepared and physicochemical properties were reported in Table 3. In order to prepare the experimental formulations, maltodextrin as binder and silicon dioxide as glidant and disintegrant were added to the extract of the plants.

The results of acceleration test of selected formulation have been shown in Table 4 . 
Table 2. Results of precompression test of powder blend of F1-F13

\begin{tabular}{|c|c|c|c|c|c|}
\hline \multirow{2}{*}{ Formulations } & \multicolumn{5}{|c|}{ Parameters } \\
\hline & \multicolumn{2}{|c|}{ Angle of repose $\left(^{\circ}\right)$} & Carr's index (\%) & \multicolumn{2}{|c|}{ Hausner ratio } \\
\hline F1 & \multicolumn{2}{|l|}{$27.33 \pm 0.65$} & $10.29 \pm 0.17$ & \multicolumn{2}{|c|}{$1.11 \pm 0.02$} \\
\hline $\mathrm{F} 2$ & \multicolumn{2}{|l|}{$27.56 \pm 0.09$} & $11.37 \pm 0.32$ & \multicolumn{2}{|c|}{$1.12 \pm 0.01$} \\
\hline F3 & \multicolumn{2}{|l|}{$28.03 \pm 0.62$} & $11.45 \pm 0.41$ & \multicolumn{2}{|c|}{$1.12 \pm 0.01$} \\
\hline $\mathrm{F} 4$ & \multicolumn{2}{|l|}{$28.54 \pm 0.40$} & $11.76 \pm 0.26$ & \multicolumn{2}{|c|}{$1.13 \pm 0.02$} \\
\hline F5 & \multicolumn{2}{|l|}{$32.84 \pm 1.02$} & $14.57 \pm 0.29$ & \multicolumn{2}{|c|}{$1.16 \pm 0.02$} \\
\hline F6 & \multicolumn{2}{|l|}{$32.55 \pm 0.02$} & $13.43 \pm 0.35$ & \multicolumn{2}{|c|}{$1.15 \pm 0.01$} \\
\hline F7 & \multicolumn{2}{|l|}{$30.67 \pm 0.23$} & $12.05 \pm 0.09$ & \multicolumn{2}{|c|}{$1.13 \pm 0.02$} \\
\hline F8 & \multicolumn{2}{|l|}{$33.41 \pm 0.43$} & $15.41 \pm 0.18$ & \multicolumn{2}{|c|}{$1.17 \pm 0.02$} \\
\hline F9 & \multicolumn{2}{|l|}{$33.89 \pm 0.66$} & $16.82 \pm 0.07$ & \multicolumn{2}{|c|}{$1.19 \pm 0.02$} \\
\hline F10 & \multicolumn{2}{|l|}{$34.85 \pm 1.13$} & $16.36 \pm 0.38$ & \multicolumn{2}{|c|}{$1.18 \pm 0.01$} \\
\hline F11 & \multicolumn{2}{|l|}{$33.60 \pm 1.42$} & $15.75 \pm 0.14$ & \multicolumn{2}{|c|}{$1.18 \pm 0.04$} \\
\hline F12 & \multicolumn{2}{|l|}{$32.66 \pm 0.83$} & $15.34 \pm 0.52$ & \multicolumn{2}{|c|}{$1.17 \pm 0.02$} \\
\hline F13 & \multicolumn{2}{|l|}{$30.34 \pm 1.01$} & $14.45 \pm 0.16$ & \multicolumn{2}{|c|}{$1.16 \pm 0.03$} \\
\hline \multicolumn{6}{|c|}{ Table 3. Physicochemical properties of the experimental formulations } \\
\hline \multirow[t]{2}{*}{ Tests } & & & Formulations & & \\
\hline & F1 & F2 & F5 & F6 & F8 \\
\hline Appearance & $\begin{array}{l}\text { Oval, Cream } \\
\text { color, } \\
\text { smooth and } \\
\text { biconvex }\end{array}$ & $\begin{array}{l}\text { Oval, Cream } \\
\text { color, smooth } \\
\text { and biconvex }\end{array}$ & $\begin{array}{c}\text { Oval, Cream } \\
\text { color with } \\
\text { white spots, } \\
\text { smooth and } \\
\text { biconvex }\end{array}$ & $\begin{array}{c}\text { Oval, Cream } \\
\text { color with } \\
\text { white spots, } \\
\text { smooth and } \\
\text { biconvex }\end{array}$ & $\begin{array}{c}\text { Oval, Cream } \\
\text { color with } \\
\text { white spots, } \\
\text { smooth and } \\
\text { biconvex }\end{array}$ \\
\hline Length (mm) & $19.44 \pm 0.03$ & $19.45 \pm 0.02$ & $19.44 \pm 0.01$ & $19.46 \pm 0.03$ & $19.44 \pm 0.01$ \\
\hline width (mm) & $8.31 \pm 0.02$ & $8.31 \pm 0.01$ & $8.32 \pm 0.01$ & $8.30 \pm 0.01$ & $8.32 \pm 0.02$ \\
\hline Thickness (mm) & $6.15 \pm 0.05$ & $6.16 \pm 0.03$ & $6.64 \pm 0.02$ & $6.63 \pm 0.03$ & $6.64 \pm 0.01$ \\
\hline Weight variation (mg) & $701.40 \pm 1.25$ & $714.36 \pm .71$ & $841.11 \pm 2.54$ & $839.48 \pm 1.14$ & $840.37 \pm 0.95$ \\
\hline Friability $(\%)$ & $0.71 \pm 0.04$ & $0.79 \pm 0.05$ & $0.69 \pm 0.05$ & $0.83 \pm 0.06$ & $0.63 \pm 0.02$ \\
\hline Hardness $\left(\mathrm{Kg} / \mathrm{Cm}^{2}\right)$ & $7.11 \pm 0.27$ & $6.78 \pm 0.18$ & $7.34 \pm 0.24$ & $6.62 \pm 0.32$ & $7.96 \pm 0.21$ \\
\hline Disintegration Time (min) & $12.43 \pm 0.17$ & $10.18 \pm 0.39$ & $13.53 \pm 0.48$ & $12.29 \pm 0.22$ & $14.50 \pm 0.34$ \\
\hline Dissolution (\%) after $60 \mathrm{~min}$ & $95.88 \pm 0.62$ & $97.67 \pm 0.16$ & $94.69 \pm 0.57$ & $96.21 \pm 0.71$ & $93.46 \pm 0.69$ \\
\hline Assay of total phenol (mg/cap) & $25.09 \pm 0.18$ & $25.15 \pm 0.13$ & $24.94 \pm 0.19$ & $25.08 \pm 0.24$ & $24.90 \pm 0.21$ \\
\hline
\end{tabular}

Table 4. Results of accelerated stability test of polyherbal tablets

\begin{tabular}{lccc}
\hline Tests & \multicolumn{1}{c}{ Results* } & 6 Months \\
\cline { 2 - 4 } Appearance & $\begin{array}{c}\text { Cream color, smooth and } \\
\text { biconvex }\end{array}$ & $\begin{array}{c}\text { Cream color, smooth and } \\
\text { biconvex }\end{array}$ & $\begin{array}{c}\text { Cream color, smooth and } \\
\text { biconvex }\end{array}$ \\
\hline Length (mm) & $19.45 \pm 0.02$ & $19.45 \pm 0.02$ & $19.45 \pm 0.01$ \\
width (mm) & $8.31 \pm 0.01$ & $8.31 \pm 0.01$ & $8.31 \pm 0.02$ \\
Thickness (mm) & $6.16 \pm 0.03$ & $6.15 \pm 0.05$ & $6.15 \pm 0.04$ \\
Weight variation (mg) & $714.36 \pm 1.71$ & $714.41 \pm 1.18$ & $714.49 \pm 1.63$ \\
Friability (\%) & $0.79 \pm 0.05$ & $0.77 \pm 0.06$ & $0.77 \pm 0.04$ \\
Hardness (Kg/Cm $\left.{ }^{2}\right)$ & $6.78 \pm 0.18$ & $6.81 \pm 0.12$ & $6.82 \pm 0.15$ \\
Disintegration Time (min) & $10.18 \pm 0.39$ & $10.22 \pm 0.45$ & $10.24 \pm 0.26$ \\
Dissolution (Total & $97.67 \pm 0.16$ & $97.59 \pm 0.32$ & $97.55 \pm 0.23$ \\
phenol content) $(\%)$ & & & $24.89 \pm 0.28$ \\
Assay of total phenol & $25.15 \pm 0.13$ & $25.03 \pm 0.21$ & \\
(mg/tab) & & & \\
\hline
\end{tabular}

* Data are expressed as means \pm SD; the stability results showed no significant differences after 6 month 
Dissolution profile analysis is an essential tool to evaluate formulation development for quality control and establishing similarity between multisource and reference formulations. A graphical representation of the percentage in drug releases of polyherbal tablets in distilled water has been shown in Fig. 1.

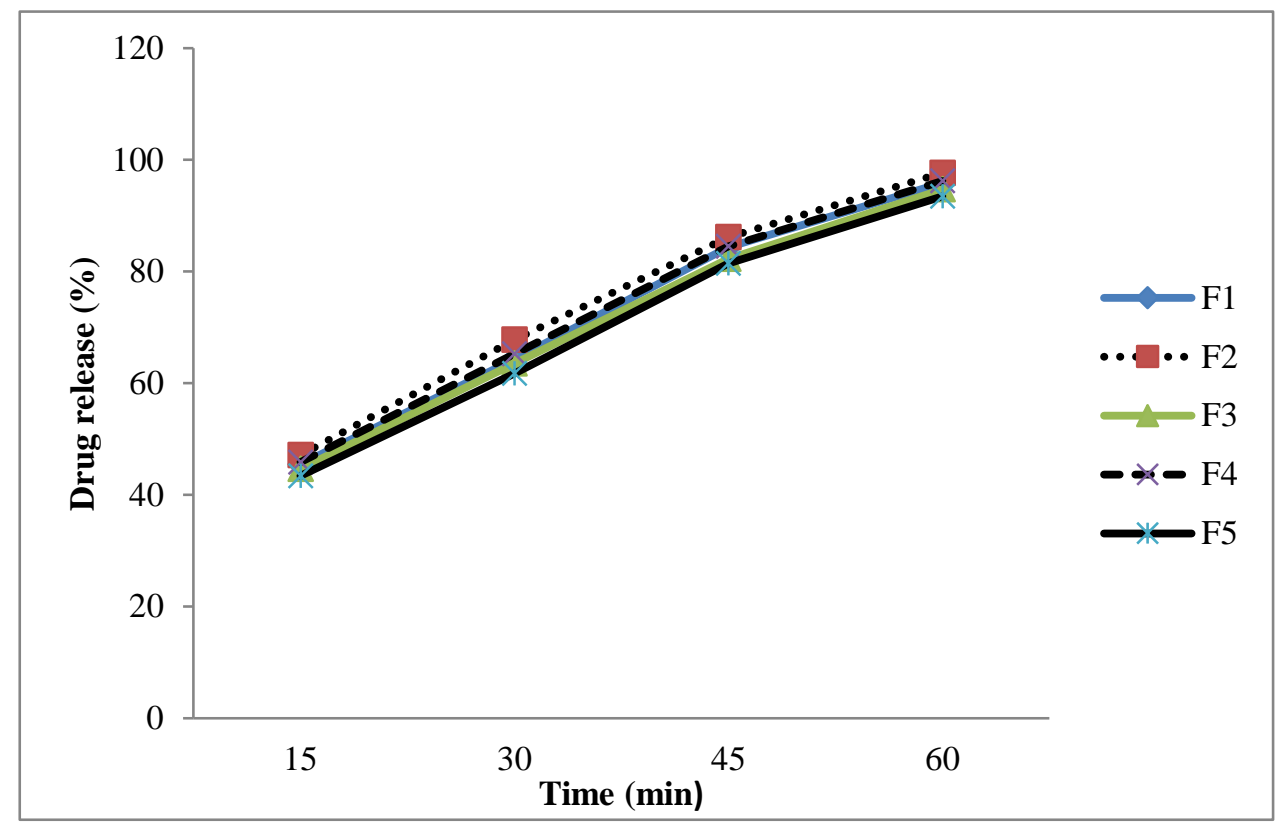

Fig. 1. Release profile of five different formulated polyherbal tablets $(n=6$, mean \pm S.D).

\section{Discussion}

There is a strong potential in the traditional and ethnomedical knowledge of different countries for developing new and efficacious drugs for the treatment of diseases as modern formulations [5, 29]. Although traditional medicines can be used as new therapeutic agents, they need to be reformulated to achieve pharmaceutical standards for modern medicine. Evaluation of the quality control parameters of the final formula will have a major role in the effectiveness and safety of the drug.

In preformulation studies of tablet formulation, angle of repose shows flowability of powders and in this search, it was between $27^{\circ}$ to $34^{\circ}$ indicating good flow characteristics of the powders. The Carr's index and Hausner ratio are indirect methods for predicting the powder flow properties. The value of Carr's index was in the range of 10-16 indicating good flow and compressibility. Hausner ratio amount was obtained below 1.19 which is in the acceptable limit of good flow indicating low interparticle friction [22]. Poor flow characteristics of formula may cause problems such as nonuniformity and weight variation problems in formulations [23]. From the above mentioned precompression results, it was found that the flowability of the powders was acceptable, so all were pressed to determine the appropriate formula according to the quality control tests.

Polyherbal tablets (F1-F13) were prepared but F3, F4 and F7 formulations did not show suitable strength and their friability exceeded the acceptable level (due to the high percentage of croscarmellose sodium), so they were discarded. 
The color of lactose-containing tablets changed over time and turned into dark brown color, indicating that lactose was incompatible with other constituents. Regarding these results, F9- F13 were not considered suitable because the drug and excipients compatibility requires an aforementioned acquaintance of physicochemical properties for the development of pharmaceutical formulation [30].

The physicochemical properties of other tablets (F1, F2, F5, F6 and F8) were evaluated and compared.

As shown in Table 3, length and width of tablets were not significantly different in formulations. The assessment of thickness and weight values demonstrated that formulations of each group showed a narrow variation range and there was a significant difference between the groups. Minimum and maximum friability of the formulations were obtained as $0.63 \%$ and $0.83 \%$, respectively. The percent of friability was less than $1 \%$ in all formulations ensuring that the tablets were mechanically stable. Another measurement of the mechanical integrity of tablets is their breaking force, which is the force required to cause them to fail (i.e., break) in a specific plane, called hardness in the pharmaceutics. The hardness of tablets was measured in the range of 6.62 to $7.96 \mathrm{~kg} / \mathrm{cm}^{2}$ that showed appropriate hardness.

Disintegration time is one of the most important factors in quality control of drugs, especially in the formulation of natural products, since lots of these compounds become sticky when they are used as powders or extracts which makes usage of disintegrants inevitable. There was a significant difference between disintegration times of formulations. The shortest disintegration time belonged to F2 with 10.18 minutes. Croscarmellose sodium as disintegrant led to faster disintegration; on the contrary, when microcrystalline cellulose was used, disintegration time increased in tablets.

Various factors such as the disintegration rate and the nature of the excipients may influence dissolution results. Sample F2 could be considered as the fastest in disintegration rate though the difference was not significant compared to other formulations. The dissolution profile indicated that at least $75 \%$ of the active ingredient was released within 45 min and was higher than $97 \%$ of labeled amount dissolved in 60 minutes for F2.

Croscarmellose sodium $2 \%$ (F1) showed more appropriate disintegration time and dissolution tests for tablets. In general, by reducing microcrystalline cellulose and increasing croscarmellose sodium, tablets hardness and disintegration time decreased and friability and dissolution increased.

Among all formulations, F2 showed more acceptable physicochemical properties. The final formulation included $500 \mathrm{mg}$ of herbal extracts mixture, $180 \mathrm{mg}$ of maltodextrin, $20 \mathrm{mg}$ silicon dioxide and $14 \mathrm{mg}$ of croscarmellose sodium per tablet (only three expedients). Less use of excipients results in the lower costs and fewer problems during formulation and production in industrial scale.

The tablets were subjected to short time accelerated stability study $\left(40{ }^{\circ} \mathrm{C} / 75 \% \mathrm{RH}\right)$ as per ICH guidelines [28]. Establishment of the drug stability plays an important role in the safety and efficacy. The final formulated tablets were cream color, biconvex with an acceptable appearance. The tablets had narrow weight variation which ensured tablet contained proper amount of medicine which maintained the good quality and effectiveness. The tablets displayed suitable hardness and friability which means they would not erode during transportation. Disintegration time was approximately 
10 minutes and the percentage of released total phenol was more than $97 \%(\mathrm{Q})$ after $60 \mathrm{~min}$ that is suitable for herbal tablets [22]. Total phenol content as the stability indicating assay of polyherbal tablets was monitored throughout the study and was found to be stable (total phenol: 25.15 to $24.89 \mathrm{mg} / \mathrm{tab}$ ). After six months, the amount of total phenolic content decreased by $1.03 \%$, which is in accordance with acceptable limits [28]. Similarly, the results of the microbiological limit tests were in accordance with WHO guidelines [31].

As the results show, no significant changes $(\mathrm{P}>0.05)$ were found in physicochemical characteristics of polyherbal tablets after 6 months at $40{ }^{\circ} \mathrm{C}$ and $75 \%$ humidity.

\section{Conclusion}

The purpose of this research was to formulate tablets of "Monzej-e-balgham" and evaluate its quality control. Various formulations were prepared and their pre-and post-formulation parameters were assessed. Among formulations, F2 was selected with its acceptable

\section{References}

1. Calixto J. Efficacy, safety, quality control, marketing and regulatory guidelines for herbal medicines (phytotherapeutic agents). Braz. J. Med. Biol. Res. 2000; 33(2): 179-189.

2. Davoodi A, Jouybari HB, Fathi $\mathrm{H}$ and Ebrahimnejad P. Formulation and physicochemical evaluation of medlar (mespilus germanica 1.) and oak (quercus castaneifolia ca mey.) effervescent tablets. Int.

J. Pharm. Sci. Res. 2018; 9(9): 3870-3875.

3. Suma TS, Ravikumar K, Somashekhar BS, Ved DK, Zaman R, Rajalakshmi G, Nair SNV and Kukkupuni SK. Documentation of 'Plant Drugs' dispensed via local weekly shanties of physicochemical characteristics and stability results and this formulation can be used after further optimization processes to mass production.

\section{Author contributions}

M. R. was involved in the experimental parts; SA. M. supervised the formulation section; Sh. F. and $\mathrm{R}$. Ch. were involved in traditional data collection; MA. Sh. conducted the pharmacological experiments; M. HM. designed and supervised the research.

\section{Conflict of interest}

The authors declare that there is no conflict of interest.

\section{Acknowledgements}

The article was based on Ph.D. thesis of Traditional Pharmacy (Maedeh Rezghi, No. 194), granted by School of Traditional Medicine, Shahid Beheshti University of Medical Sciences, Tehran, Iran (No. 189).

Madurai City, India. J. Ayurveda Integr. Med. 2018; 9(2): 104-112. doi: 10.1016/j.jaim.2017. 05.008 .

4. Zargaran A, Daneshamouz S, Kordafshari $G$ and Mohagheghzadeh A. Renovation of a traditional Ergh-al-Nassa pill (Hab) to a standard Pharmaceutical molded tablet. Pak. J. Pharm. Sci. 2016; 29(5): 1703-1709.

5. Moein $\mathrm{E}$, Hajimehdipoor $\mathrm{H}$, Toliyat $\mathrm{T}$, Choopani $\mathrm{R}$ and Hamzeloo-Moghadam $\mathrm{M}$. Formulation of an aloe-based product according to Iranian traditional medicine and development of its analysis method. DARU J. Pharm. Sci. 2017; 25(1): 19-27. doi: 10.1186/ 
s40199-017-0185-x.

6. Fahimi S, Mortazavi SA, Abdollahi M and Hajimehdipoor $H$. Formulation of a traditionally used polyherbal product for burn healing and HPTLC fingerprinting of its phenolic contents. Iran. J. Pharm. Res. 2016; 15(1): 95-105.

7. Zargaran A, Zarshenas MM, Karimi A, Yarmohammadi $\mathrm{H}$ and Borhani-Haghighi $\mathrm{A}$. Management of stroke as described by Ibn Sina (Avicenna) in the Canon of Medicine. Int. J. Cardiol. 2013; 169(4): 233-237. doi: 10. 1016/j.ijcard.2013.08.115.

8. Yarmohammadi $\mathrm{H}$ and Dalfardi B. AlAkhawayni's views on stroke. Int. J. Cardiol. 2014; 172(3): 598. doi: 10.1016/j.ijcard.2014. 01.061 .

9. Ahmed A, Ansari AN, Ali SJ and Yasir M. Efficacy of Munzij wa Mushil-e-Balgham (poly herbal formulations) and massage with Roghan-e-Malkangani in Falij Nisfi (Hemiplegia): a randomised controlled clinical trial. Int. J. Pharm. Sci. Res. 2015; 6(1): 453458. doi: 10.13040/IJPSR.0975-8232.

10. Upur H, Dubrovin D and Amat N. Letter to the Editor: Avicenna's view on the prevention of thrombosis. Int. J. Cardiol. 2013; 168(1): 577-578. doi: 10.1016/j.ijcard. 2013.01.279.

11. Dabbaghmanesh $\mathrm{MH}$ and Gordon Ferns MD D. Effects of body electroacupuncture on plasma leptin concentrations in obese and overweight people in Iran: a randomized controlled trial. Altern. Ther. Health Med. 2013; 19(2): 24.

12. Xilifu $D$, Nurmuhammat $A$ and Halmurat U. Abnormal Balgham Munziq, a Uighur herbal medicine formula, has been recently shown to possess extensive cardiovascular pharmacological activities. Atherosclerosis 2016; 252: 87. doi: 10.1016/j. atherosclerosis.2016.07.523.

13. Yuemaier $M$, Tuerhong $M$, Keremu A, Kadeer N, Aimaiti A, Wushouer X, Yiming A and Yilike $\mathrm{X}$. Research on establishment of abnormal phlegmatic syndrome with premature ovarian failure rat model and effects of Balgham Munziq treatment. Evid. Based. Complement. Alternat. Med. 2018. Article ID 3858209. doi: 10.1155/2018/ 3858209.

14. Adilijiang $Y$, Liu F, Maowulan $M$ and Zhang P. The study of erectile changes of abnormal balgam syndrome with impotence rats model and the gonad axial mechanism. Transl. Androl. Urol. 2015; 4(1): 105. doi: 10.3978/j.issn.2223-4683.2015.s105.

15. Quddus A, Siddiqui M, Siddiqui $M$ and Aleem S. Clinical evaluation of the efficacy of Qurs Sartan Kafoori and Sharbat Zoofa Murakkab in chronic bronchitis. Indian $J$. Tradit. Know. 2009; 8(3): 417-420.

16. Aibai S, Anzhaer A, Aimaiti A, Islam R, Aimaiti $G$ and Abuduaini A. Association analysis of traditional Uighur medicine differential syndrome typing with biochemical parameters in serum and lesional tissue fluid of vitiligo patients. Eur. J. Integr. Med. 2015; 7(6): 653-656.

17. Aimaiti $\mathrm{N}$ and Wufuer $\mathrm{H}$. Effect of abnormal Balgham Munziq aqueous extracts and ethanol extracts on proliferation, tyrosinase activity and melanogenesis of B16 Murine Melanoma. Planta Med. 2011; 77(12): 77. doi: 10.1055/s-0031-1282835.

18. Shah Arzani MA. Mizan Al-teb. 1st ed. Sama Cultural Institute. Qom. 2002, pp: 23-4.

19. Iranian Herbal Pharmacopoeia Committee. 
Iranian Herbal Pharmacopoeia. 1st ed. Ministry of Health and Medical Education of Iran, Food and Drug Administration. Tehran. 2002, pp: 200-5.

20. The British Pharmacopoeia Commission. British pharmacopoeia. Vol 4. The Stationary Office. London. 2011, pp: 189-95, 264-8.

21. Pharmacopoeia Commission for Indian. The Unani Pharmacopoeia of India. Department of AYUSH, Ministry of Health \& Family Welfare, Govt. of India. New Delhi. 2016, pp: 11-2, 31-3, 96-7.

22. The US Pharmacopoeial Committees. United States Pharmacopoeia XXXVII, National Formulary XXXII. Vol 1. United States Pharmacopoeial Convention. Rockville (MD). 2014, pp: 341-56.

23. Aulton ME and Taylor KM. Aulton's pharmaceutics: the design and manufacture of medicines. 5th ed. Elsevier Health Sciences. London. 2017, pp: 346-52.

24. Allen L and Ansel HC. Ansel's pharmaceutical dosage forms and drug delivery systems. 9th ed. Lippincott Williams \& Wilkins. Philadelphia. 2013, pp: 184-92.

25. Cerciello A, Auriemma G, Del Gaudio P, Cantarini $M$ and Aquino RP. Natural polysaccharides platforms for oral controlled release of ketoprofen lysine salt. Drug Dev. Ind. Pharm. 2016; 42(12): 2063-2069. doi: 10.1080/03639045.2016.1195401.

26. Osei-Yeboah F and Sun CC. Validation and applications of an expedited tablet friability method. Int. J. Pharm. 2015; 484(1-2): 146155. doi: 10.1016/j.ijpharm.2015. 02.061.

27. United States Pharmacopeia (USP). Pharmacopeial Convention, Inc., Rockville, MD, 2015.

28. ICH Expert Working Group. Stability testing of new drug substances and products. Q1A (R2). Current Step 4. ICH Harmonised Tripartite Guideline. London. 2003.

29. Shivakumar A, Paramashivaiah S, Anjaneya RS, Hussain J and Ramachandran S. Pharmacognostic evaluation of triphala herbs and establishment of chemical stability of Triphala caplets. Int. J. Pharm. Sci. Res. 2016; 7(1): 244-251. doi: 10.13040/IJPSR.09758232.7(1).244-51.

30. Pani N, Nath $L$ and Acharya S. Compatibility studies of nateglinide with excipients in immediate release tablets. Acta Pharm. 2011; 61(2): 237-247. doi: 10. 2478/v10007-011-0016-4.

31. World Health Organization. Quality control methods for herbal materials. WHO Press. Geneva. 2011, pp: 75-83.

How to cite this article: Rezghi M, Mortazavi SA, Fahimi Sh, Choopani R, Sheikholeslami MA, Hamzeloo-Moghadam M. Polyherbal tablet based on Iranian traditional medicine. Journal of Medicinal Plants 2021; 20(77): 15-25.

doi: 10.29252/jmp.20.77.15 


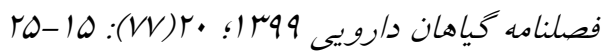

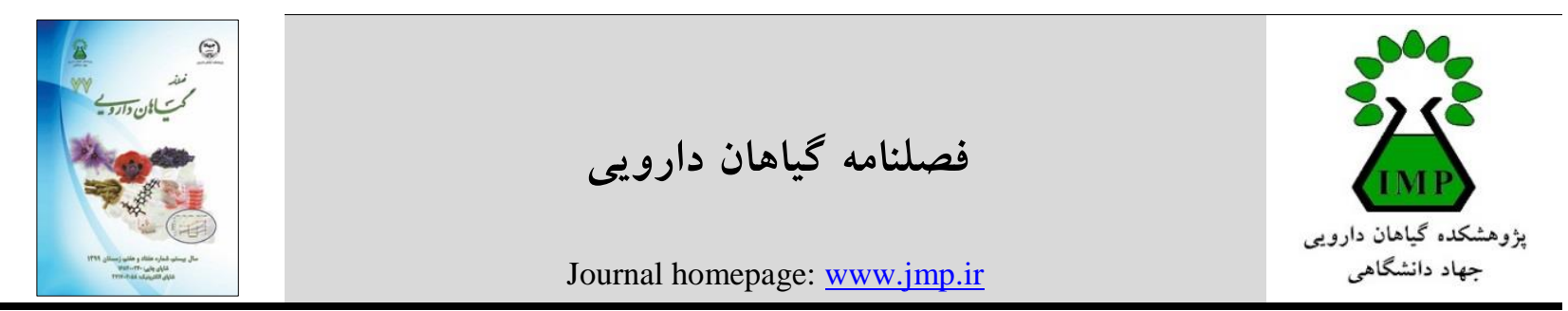

مقاله تحقيقاتى

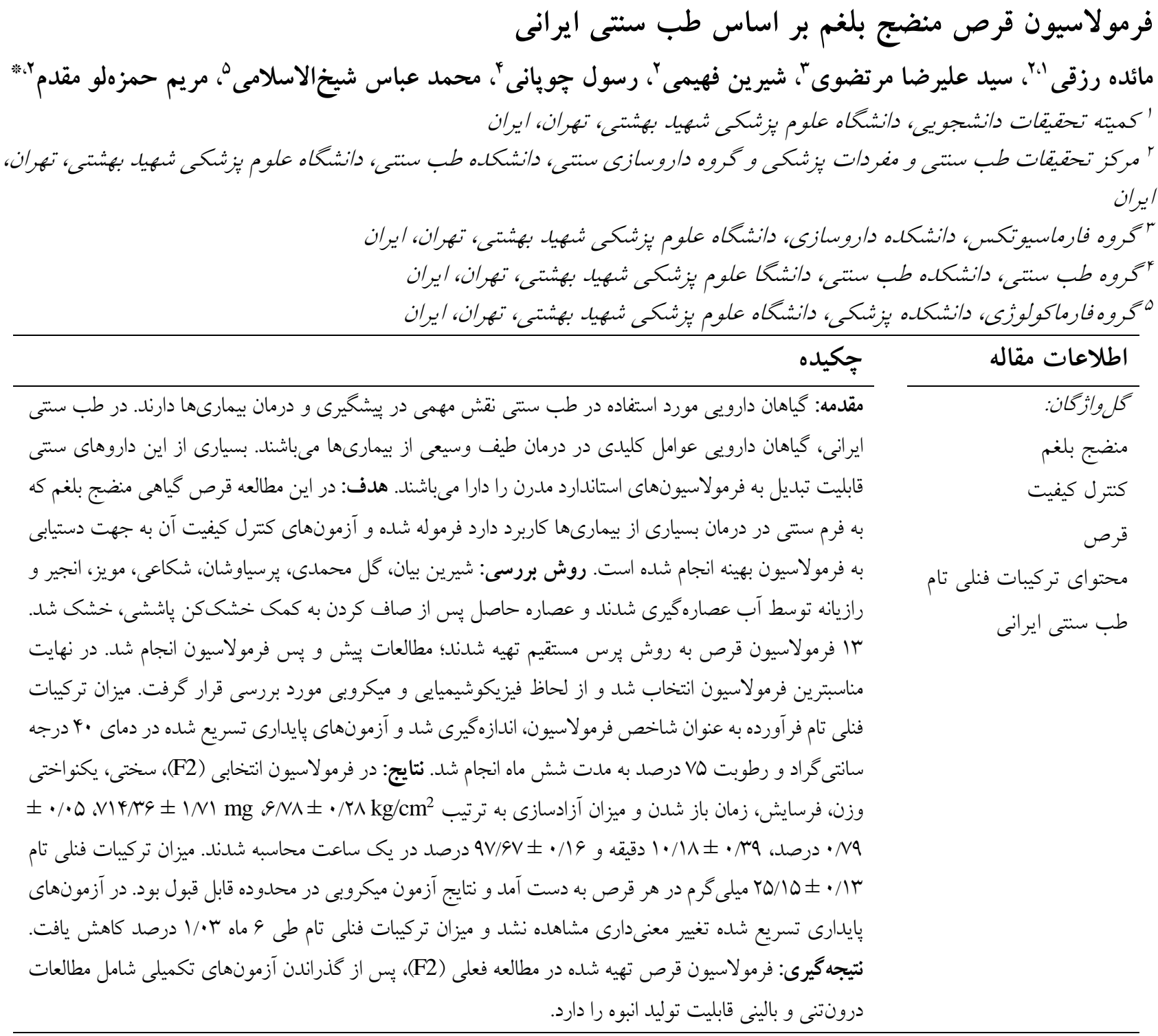

مخفف ها: ITM، طب سنتى ايرانى؛ ICH، شوراى بين المللى هماهنكى الزامات فنى

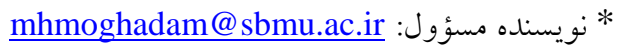
doi: $10.29252 /$ jmp.20.77.15

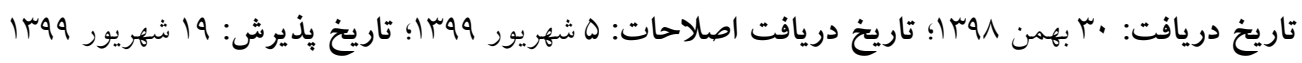

(C) 2020. Open access. This article is distributed under the terms of the Creative Commons Attribution-NonCommercial 4.0 International License (https://creativecommons.org/licenses/by-nc/4.0/) 